

\section{Biodata Penulis}

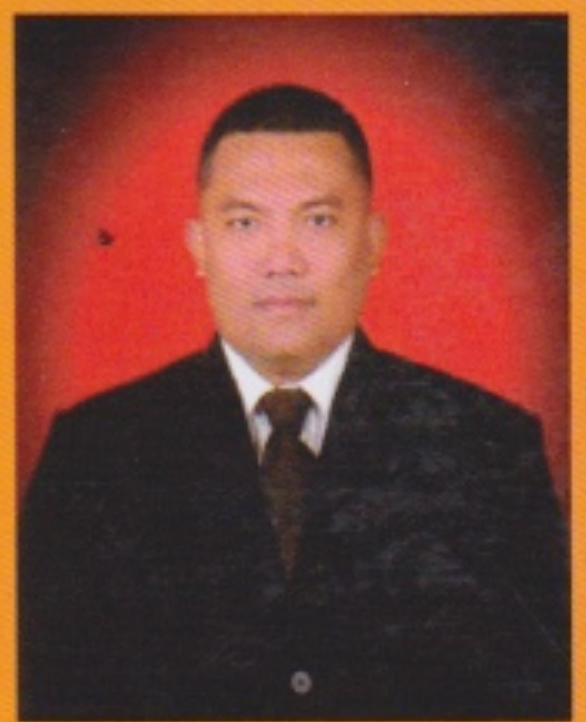

Roymon Panjaitan SE, Ak, MM lahir di Jakarta, 15-10 -1981, putera dari Bapak M. Abidan Panjaitan, SH (Am) dan Nurhaida Sirait. Menyelesaikan Program S1 Akuntansi dari Universitas Tarumanagara, selama studi penulis aktif dalam kegiatan organisasi dan menjadi anggota Junior Ikatan Akuntan Indonesia (IAI) setelah lulus, penulis melanjutkan program profesi PPAk sambil bekerja dalam beberapa perusahaan yang berkaitan dalam bidang auditor, keuangan dan perpajakan.

Beberapa kasus Perusahaan Asing, Konsultan SDM dan Kantor Akuntan Publik yang ditangani penulis selama bekerja. Penulis kemudian menyelesaikan program Studi S2 Magister Manajemen konsentrasi Keuangan di Universitas Jayabaya sambil bekerja di Bank BTPN, Tbk kurang lebih dalam waktu 10 tahun, selama bekerja penulis memiliki pengalaman dalam bidang kredit administrasi, marketing officer dan kredit analis portofolio kredit, selain itu penulis telah mengikuti Sertifikasi Kredit Pensiun dan beberapa pelatihan dalam peningkatan kinerja perusahaan seperti pelatihan Marketing Skill, Pelatihan dasar kepemimpinan, Digitalisasi Fintech, dII.

Saat ini masih aktif dalam penulisan jurnal tentang analisa laporan keuangan dan menjadi motivator bagi perusahaan untuk strategi marketing dan analisa resiko kredit.

PENERBIT SUKARNO PRESSINDO

Karanggawang Barat RT 05 BW 14 Kel. Tandang Kec. Tembalang, Kota Semarang 50274 Phone: 081228494410; 08976759734

Emall : sukarnopressindo\&gmaileom $\$$ sukarnopressagmaileom Website wnw sukarmopressindo.com 6 www.karnopresscom

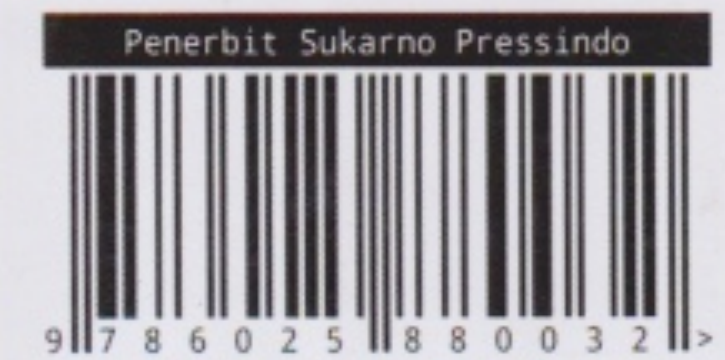

ISBN 978-602-5880-03-2 


\title{
MANAJEMEN PEMASARAN
}

\author{
ROYMON PANJAITAN, SE, Ak, MM
}

Editor: SUKARNO, SIP,SS

PENERBIT SUKARNO PRESSINDO

2018 


\section{MANAJEMEN PEMASARAN}

ISBN: 978-602-5880-03-2

Setting and Layout : Anis

Cover Design: Sukarno

Editor: Sukarno, SIP, SS

\section{Penerbit: PENERBIT SUKARNO PRESSINDO}

Karanggawang Barat RT 05 RW $14 \mathrm{Kel}$. Tandang.

Kec. Tembalang Kota Semarang 50274

No HP. $081228494410 ; 08976759734$

Email: sukarnopressindo@gmail.com; sukamopress@ gmail.com

Website: www.karnopress.com \& www.sukarnopressindo.com

Penerbit Sukarno Pressindo menerima kiriman naskah (puisi, cerpen, novel, buku), Naskah merupakan hasil karya sendiri/bukan plagiat, tidak menyinggung SARA, tidak bertentangan dengan Pancasila\&UUD 1945. Penulis bertanggung jawab penuh atas jisi buku.

Naskah diketik rapi, kirim ke: sukarnopressindo(a gmail.com; sukarnopress@a gmail.com

\section{Hak Cipta 9 Penulis}

Hak cipta ada pada penulis. Hak cipta dilindungi oleh UU. Dilarang menggandakan, memperbanyak, atau menyebarluaskan sebagian atau seluruh isi buku ini dalam bentuk apa pun, dengan cara apa pun dan untuk tujuan apa pun tanpa izin tertulis dari penerbit. 


\section{DAFTAR ISI}

Halaman

HALAMAN JUDUL....................................................................... i

KATA PENGANTAR ............................................................................ ii

DAFTAR ISI …............................................................................ ii

DAFTAR GAMBAR ......................................................................... iv

\section{BAB I DEFINISI PEMASARAN}

1.1. Latar Belakang ........................................................... 2

1.2. Pengertian Pemasaran ............................................... 6

1.3. Pengertian Proses Manajemen Pemasaran .................... 7

1.4. Fungsi dan Orientasi Manajemen Pemasaran.................. 11

1.5. Audit Pemasaran ............................................................... 18

1.6. Rangkuman ........................................................ 22

1.7. Soal untuk diskusi ............................................... 24

BAB II PENERAPAN STRATEGI PEMASARAN

2.1. Konsep Pemasaran dengan Perencanaan Strategis .......... 26

2.2. Proses Analis dan Pilihan Strategis ................................ 29

2.3. Analisis SWOT ............................................................ 34

2.4. Jenis - jenis Strategi Pemasaran.................................... 42

2.5. Bauran Pemasaran (Marketing Mix )............................ 49

2.6. Rangkuman..................................... 55

2.7. Soal untuk diskusi ...................................................... 59

BAB III SISTEM INFORMASI DAN RISET PEMASARAN

3.1. Sistem Informasi Pemasaran ........................................ 61

3.2. Riset Pemasaran ........................................................ 65

3.3. Mengukur Produktivitas Pemasaran .............................. 73 


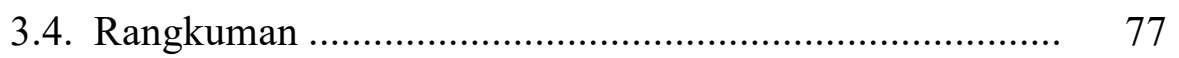

3.5. Soal untuk diskusi ...................................................... 78

BAB IV ANALISA PERILAKU KONSUMEN

4.1 Pengertian Perilaku Konsumen ........................................ 80

4.2 Proses Psikologi Kunci $\quad$................................................... 87

4.3 Langkah Pengambilan Keputusan Pembelian .................. 89

4.4 Riset Perilaku Konsumen ................................................ 90

4.5. Rangkuman........................................ 92

4.6 Soal untuk Diskusi ....................................... 93

BAB V ANALISA PASAR BISNIS

5.1 Pengertian Pasar Bisnis ..................................................... 95

5.2 Karakteristik Pasar Bisnis $\quad$.............................................. 95

5.3 Proses Keputusan Pembelian ............................................ 96

5.4 Pasar Lembaga dan Pemerintah ....................................... 99

5.5. Rangkuman......................................... 101

5.6 Soal untuk Diskusi .................................. 106

BAB VI IDENTIFIKASI, SEGMEN, TARGET DAN POSISI PASAR

6.1 Segmentasi ..................................................................... 103

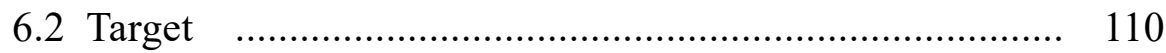

6.3 Posisi Pasar ................................................................... 112

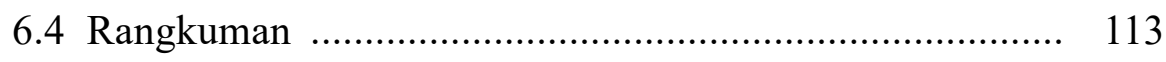

6.5. Soal untuk Diskusi....................................... 113

BAB VII PRODUK, JASA DAN STRATEGI PENETAPAN MERK

7.1 Produk ............................................................................ 115

7.2 Strategi Penetapan Merk .............................................. 119

7.3 Pemasaran Jasa.................................................................. 112

7.4 Rangkuman ............................................................... 125 
BAB VIII INOVASI PRODUK DAN STRATEGI SIKLUS PRODUK

8.1 Strategi Inovasi Produk ................................................. 128

8.2 Strategi Siklus Hidup Produk ................................... 130

8.3 Pertimbangan Tambahan Produk dan Jasa ..................... 133

8.4 Rangkuman .............................................................. 135

8.5. Soal untuk Diskusi.................................. 136

BAB IX BAURAN PEMASARAN - LOKASI DAN SALURAN DISTRIBUSI

9.1 Kegunaan Lokasi dan Saluran distribusi ....................... 138

9.2 Tipe - tipe Distribusi .............................................. 138

9.3 Evaluasi Saluran dan Usaha Pengendalian Distribusi ....... 141

9.4 Manajemen Konflik dan Saluran Distribusi ................... 142

9.5. Rangkuman.................................... 145

9.6. Soal untuk Diskusi.................................. 147

BAB X BAURAN PEMASARAN - HARGA DAN PROMOSI

10.1 Pengertian dan Tujuan Penetapan Harga ....................... 149

10.2 Faktor yang Mempengaruhi Penetapan Harga ............... 150

10.3 Metode Penetapan Harga.............................................. 152

10.4. Rangkuman..................................... 168

10.5. Soal untuk Diskusi.................................. 171

DAFTAR PUSTAKA 


\section{DAFTAR GAMBAR}

Gambar 1 Model Sederhana proses pemasaran ...................................... 7

Gambar 2 Costumer Service Satisfaction \& Call Centre............................ 10

Gambar 3 Fungsi Manajemen Pemasaran ................................................... 11

Gambar 4 Proses pengevaluasian kegiatan pemasaran.............................. 15

Gambar 5 Perbedaan konsep penjualan dan konsep pemasaran.................... 17

Gambar 6 Model proses pemasaran yang diperluas ................................... 23

Gambar 7 Model proses perencanaan strategis ........................ 28

Gamabar 8 Proses Analisis Kasus..................................... 32

Gambar 9 Bagan analisis SWOT .................................... 35

Gambar 10 Metode Analisis Kuadran................................. 36

Gambar 11 Empat P (4P) dari bauran pemasaran........................ 49

Gambar 12 Marketing Mix 4C ..................................... 51

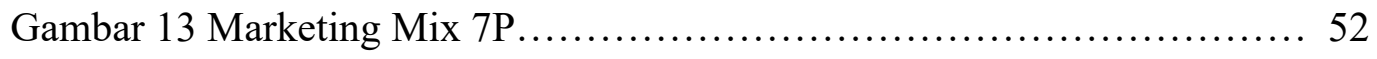

Gambar 14 Sistem Informasi Pemasaran............................. 61

Gambar 15 Faktor yang mempengaruhi perilaku konsumen................ 81

Gambar 16 Model sederhana mengenai proses sosialisasi.................. 85

Gambar 17 Hierarki Kebutuhan Maslow............................... 88

Gambar 18 Langkah Pengambilan Keputusan Pembeli..................... 89

Gambar 19 Proses Riset Perilaku Konsumen............................. 91

Gambar 20 Tahap - tahap dalam proses pembelian bisnis............... 97

Gambar 21 Keputusan Strategi merk Utama.............................120

Gambar 22 Karakteristik Jasa.......................................... 122 


\section{BAB I}

\section{DEFINISI PEMASARAN}

\section{Setelah mempelajari bab ini, Anda diharapkan untuk :}

1. Mendefinisikan pemasaran dan membuat kerangka langkah proses pemasaran.

2. Pentingnya memahami pelanggan dan pasar.

3. Mengidentifikasikan dan memahami lima konsep inti pasar.

4. Mengidentifikasikan elemen kunci dari strategi pemasaran

5. Mendiskusikan orientasi manajemen pemasaran dan hubungan pelanggan.

6. Mengidentifikasikan strategi penciptaan nilai bagi pelanggan sebagai imbalan.

7. Mendiskusikan kekuatan utama pemasaran dalam era hubungan saat ini.

8. Mengidentifikasi pentingnya sistem audit pemasaran dalam evaluasi strategi.

9. Menggambarkan seluruh isi bab ini dan sekaligus mampu untuk mendiskusikannya.

\subsection{Latar Belakang}


Suatu kegiatan usaha ( bisnis ) yang dijalani oleh suatu perusahaan, tentulah memiliki beberapa tujuan yang ingin dicapai oleh pemilik dan manajemen. Untuk meningkatkan penjualan produk atau jasa yang optimal, pemilik perusahaan berusaha mencari strategi bisnis dengan berbagai konsep pemasaran apa yang akan dilakukan untuk meningkatkan penjualan produk atau jasa mereka. Mengapa ? Karena setiap pemilik ingin menguasai pasar dengan produk andalan mereka sampai memperoleh keuntungan yang besar dan produk mereka dapat dikenal lebih luas dan berusaha menjadi pemenang dalam persaingan pasar secara dinamis.

Bagi pihak manjemen, keuntungan yang diperoleh merupakan pencapaian rencana (target) yang telah ditentukan sebelumnya. Pencapaian target keuntungan sangat penting karena dengan mencapai target yang telah ditetapkan atau melebihi target yang diinginkan, hal ini merupakan prestasi tersendiri bagi pihak manajemen. Prestasi ini menjadi ukuran untuk menilai kesuksesan manajemen pemasaran dalam mendistribusikan produknya ke dalam pasar . Demikian pula sebaliknya apabila manajemen gagal mencapai target, hal ini merupakan cermin kegagalan manajemen dalam mengelola perusahaan. Kegagalan mencapai target pemasaran itu sendiri dapat merusak citra produk berupa barang atau jasa, sehingga akan menimbulkan ketidakpercayaan terhadap inovasi produk terbaru bagi pemilik atau manajemen perusahaan.

Kedua, Pemilik menginginkan usaha lewat pemasaran produk yang ditawarkan tidak hanya untuk satu periode saja. Artinya pelaku usaha menginginkan pemasaran produk memiliki umur yang panjang untuk beberapa periode tahun ke depan dan bukan seumur jagung. Bahkan bila perlu, pelaku usaha menginginkan perusahaannya hidup sampai beberapa keturunan. Demikian pula pihak manajemen pemasaran juga menginginkan produknya terus berinovasi dan tentunya dikenal lebih lama selama perusahaan hidup.

Tujuan ketiga, adalah perusahaan tetap mampu menyediakan barang berupa produk dan jasa untuk kepentingan masyarakat umum. Tersedianya produk dan jasa juga berarti mampu memberikan kemakmuran bagi masyarakat. Masyarakat memiliki tambahan pilihan jenis barang atau jasa dengan kualitas atau harga yang lebih kompetitif. Lebih dari itu, kehadiran barang dan jasa akan ikut membantu pemerintah dalam menyediakan berbagai jenis dan jumlah barang yang dibutuhkan di dalam negeri. Bagi pemerintah, jika pemasaran dengan mengekspor barang tentunya akan menghasilkan devisa Negara jika dapat menanggulangi atau mengganti produk yang semula masih diimpor.

Tidak ada zona yang benar - benar nyaman dalam bisnis, sama halnya dalam pemasaran produk barang atau jasa, berbagai macam bisnis pemasaran produk terus menerus mengalami perubahan yang cepat. Atas perubahan - perubahan yang terjadi, sebagian pelaku bisnis tidak 
menyadarinya dan terlena dengan zona yang sudah dirasakan nyaman. Mereka masih tetap menggunakan konsep dan strategi pemasaran yang konvensional, karena menganggap perusahaan masih profit dari strategi tersebut dan belum dapat tersaingi di pasar, padahal persaingan bisnis dengan inovasi terbaru sudah semakin inovatif, canggih dan cepat. Hal ini yang harus cepat ditanggapi oleh pelaku manajemen pemasaran, karena manajemen pemasaran adalah sebagai ujung tombak dalam pemasaran produk. Kompetisi pasar dalam era globalisasi saat ini membutuhkan analisa, konsep dan inovasi strategi yang terbaru supaya dapat dikenal dan tentunya tercapai dalam target penjualan.

Contoh yang sangat menarik adalah Perusahaan Nokia dan Blackbarry. Keduanya adalah brand raksasa pada beberapa tahun pertama kemunculannya. Pada saat brand lain kemudian menawarkan sistem operasi android, dan kemudian terbukti banyak orang menikmati dan nyaman dengan layanan itu, Nokia tetap mempertahankan sistem operasi syimbian andalannya. Demikian juga dengan Blackbarry yang keras kepala mempertahankan tuts Qwerty pada saat konsumen begitu menikmati layanan full touch screen yang ditawarkan oleh brand lain. Akibatnya dua brand raksasa tersebut kemudian gulung tikar, tergeser oleh Samsung dan Apple.

Kebangkrutan juga pasti akan dialami oleh Samsung dan Apple, jika keduanya nyaman dengan capaian saat ini dan berhenti melakukan inovasi. Singkatnya, pelaku bisnis apapun harus siap melakukan perubahan - perubahan untuk memenangkan persaingan yang semakin ketat. Selain inovasi yang dilakukan oleh perusahaan - perusahaan besar, sasaran pemasaran adalah menarik pelanggan baru dengan menjanjikan keunggulan nilai - nilai serta menjaga dan menumbuhkan pelanggan yang ada dengan memberikan kepuasan.

Salah satu contoh kepuasan pelanggan saat ini yang sudah dirasakan oleh sebagian masyarakat dengan adanya aplikasi transportasi berbasis online yaitu : GoJek, Grab, dll. Dalam penggunaan aplikasi ini konsumen sangat dimanjakan dengan kehadiran aplikasi tersebut. Bagaimana tidak ? Penumpang dengan hanya mendownload dan mendaftarkan emailnya di telephone seluler bisa langsung terhubung dengan aplikasi tersebut, yang kegunaannya sangat membantu penumpang dalam transportasi dari satu tempat ke tempat tujuannya. Proses sangat cepat didukung dengan kecepatan order pemesanan, harga terjangkau dan tentunya hal yang sangat diperhatikan adalah masalah kenyamanan yang berhubungan dengan kepuasan pelanggan, karena supir online akan dievaluasi oleh penumpang dalam kinerjanya dengan memberikan penilaian terhadap performa supir di aplikasi tersebut. Hal ini sangat memperhatikan kebutuhan dan mengutamakan kenyamanan 
pelanggan dalam pelayananannya, sehingga pelaku bisnis tersebut dapat mempertahankan dan berfokus pada pelanggan dan mempunyai komitmen yang kuat pada pemasaran.

Secara formal atau informal, orang dan organisasi terlibat dalam sejumlah besar aktivitas yang kita sebut pemasaran. Pemasaran yang baik telah menjadi elemen yang semakin vital untuk kesuksesan bisnis. Kesuksesan finansial sering bergantung pada kemampuan pemasaran. Finansial, operasi akuntansi, dan fungsi bisnis lainnya tidak akan berarti jika tidak ada cukup permintaan akan produk dan jasa sehingga perusahaan bisa menghasilkan keuntungan Harus ada pendapatan agar laba didapat. Pemasaran sangat mempengaruhi kehidupan kita setiap hari. Pemasaran melekat dalam setiap hal yang kita lakukan dari pakaian yang kita pakai, situs internet yang kita klik, hingga iklan yang kita lihat.

Pentingnya pemasaran berdasarkan hasil survei kepada pemilik perusahaan saat ini yaitu tantangan mereka terhadap pertumbuhan pendapatan yang stabil dan berkelanjutan dan loyalitas/retensi pelanggan. Pencapaian hal tersebut sangat bergantung pada pemasaran. Para pemilik barang atau jasa sebagai pelaku pasar mengetahui pentingnya pemasaran untuk membangun merek dan basis pelanggan yang loyal, yang merupakan asset tak berwujud yang membentuk persentase nilai yang besar dari sebuah perusahaan

Membuat keputusan yang benar tidak selalu mudah. Para manajer pemasaran harus memutuskan fitur apa yang ddiciptakan pada produk, harga yang ditawarkan kepada pelanggan, dimana mereka harus menjual produk dan berapa jumlah anggaran yang harus dihabiskan untuk iklan, penjualan atau Internet. Mereka juga harus memutuskan detail seperti kata-kata atau warna yang tepat untuk kemasan baru. Perusahaan yang menanggung resiko lebih besar adalah perusahaan yang tidak memantau pelanggan dan pesaingnya dengan cermat dan terus meningkatkan nilai yang ditawarkan kepada pelanggan. Mereka memandang bisnisnya hanya dari sudut jangka pendek yang digerakkan oleh penjualan dan akhirnya gagal dalam pihak memuaskan pihak internal perusahaan maupun eksternal perusahaan.

Pemasaran yang baik bukan sebuah kebetulan, melainkan hasil dari perencanaan dan pelaksanaan yang cermat. Pemasaran adalah seni sekaligus ilmu ada ketegangan yang terus menerus antara sisi terfomulasikan dan sisi kreatifnya. Lebih mudah mempelajari sisi terformulasikan yang akan menjadi fokus perhatian. Pemasaran yang cerdas adalah usaha yang tak berkesudahan. 


\subsection{Pengertian Pemasaran}

Pemasaran adalah ilmu dan seni menjelajah proses sosial atau manajerial dimana pribadi atau organisasi memperoleh apa yang mereka butuhkan dengan menciptakan, menawarkan dan mempertukarkan produk kepada pihak lain bertujuan membangun hubungan yang kuat dengan pelanggan dan memperoleh nilai dari pelanggan atau konsumen.

American Marketing Asociation (AMA) mendefinisikan pemasaran sebagai berikut : Pemasaran adalah suatu fungsi organisasi dan serangkaian proses untuk menciptakan, mengkomunikasikan, dan memberikan nilai kepada pelanggan dan untuk mengelola hubungan pelanggan dengan cara yang menguntungkan organisasi dan pemangku kepentingannya. 
Perbedaan pemahaman pemasaran ditinjau dari definisi sosial dengan definisi manajerial yaitu pada definisi sosial adalah sebuah proses kemasyarakatan dimana individu dan kelompok memperoleh apa yang mereka butuhkan dan inginkan dengan menciptakan , menawarkan dan secara bebas mempertukarkan produk dan jasa yang bernilai dengan orang lain. Sedangkan, pemahaman pemasaran ditinjau dari definisi manajerial saat ini pemasaran sebagai "seni menjual produk". Pemahaman ini sudah menjadi pemahaman yang sudah menjadi puncak "gunung es", karena menjual bukanlah menjadi hal terpenting dalam pemasaran, tetapi lebih penting untuk mengetahui dan memahami pelanggan dengan baik sehingga produk atau jasa bisa sesuai dengan kebutuhannya sehingga terjual.

\section{Peranan Pemasaran}

Peranan pemasaran tidak hanya menyampaikan produk atau jasa kepada konsumen, tetapi juga bagaimana produk atau jasa tersebut dapat memberikan kepuasan pelayanan kepada konsumen atau pelanggan dengan menghasilkan laba. Sasaran dari pemasaran adalah dengan menarik pelanggan baru dengan menjanjikan kualitas atau nilai superior, menetapkan harga yang menarik pembeli, pendistribusian produk dengan mudah, mempromosikan secara efektif serta mempertahankan pelanggan yang sudah ada dengan mengutamakan kepuasan pelanggan.

\subsection{Pengertian Proses Manajemen Pemasaran}

Manajemen Pemasaran adalah suatu usaha untuk merencanakan, mengimplementasikan (yang terdiri dari kegiatan mengorganisasikan, mengarahkan, mengkoordinir) serta mengawasi atau mengendalikan kegiatan pemasaran dalam suatu organisasi agar tercapai tujuan organisasi secara efisien dan efektif. Tujuan manajer perusahaan adalah menemukan, menarik, mempertahankan, dan menumbuhkan pelanggan sasaran dengan menciptakan, memberikan, dan mengkomunikasikan keunggulan produk atau jasa kepada konsumen.

\section{Proses Pemasaran}

Pemasar harus memahami kebutuhan dan keinginan pelanggan dimana mereka beroperasi. 5 konsep inti pelanggan dan pasar : (1) kebutuhan, keinginan dan permintaan ; (2) 
penawaran pemasaran (produk, jasa dan pengalaman); (3) nilai dan kepuasan; (4) pertukaran dan hubungan; dan (5) pasar.

Menciptakan nilai untuk pelanggan dan membangun hubungan pelanggan
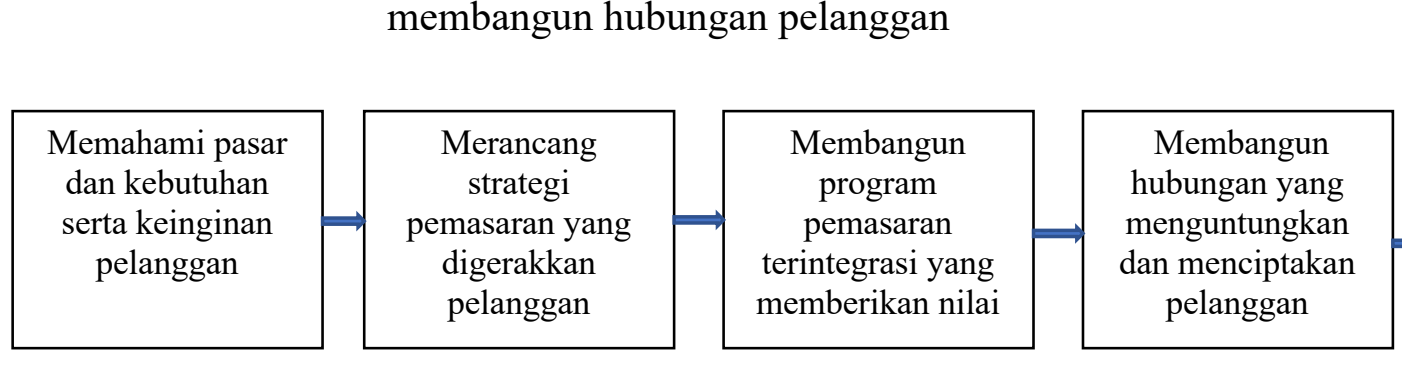

Menangkap nilai dari pelanggan untuk keuntungan dan ekuitas pelanggan

Gambar 1. Model sederhana proses pemasaran ( Philip Kotler \& Gary Armstrong, 2008 )

\section{Kebutuhan, Keinginan dan Permintaan Pelanggan}

Konsep paling dasar yang mendasari pemasaran adalah Keinginan (Wants), Kebutuhan (Needs), dan Permintaan (Demands). Kebutuhan adalah keadaan dari perasaan kekurangan, kebutuhan ini meliputi kebutuhan fisik seperti makanan, pakaian, kehangatan dan keamanan; keburuhan sosial seperti perhatian, pengetahuan akan ekspresi diri. Kebutuhan itu adalah bagian dasar dari sifat kodrati manusia.

Keinginan adalah merupakan kebutuhan manusia yang terbentuk oleh budaya dan kepribadian seseorang. Keinginan terbentuk oleh masyarakat dan berguna untuk memuaskan kebutuhan masyarakat.

Permintaan terjadi ketika didukung oleh daya beli masyarakat untuk kemampuan dia memenuhi permintaannya lewat produk yang memberi tambahan nilai dan kepuasan yang paling tinggi.

\section{Penawaran Pasar-Produk, Jasa dan Pengalaman.}


Beberapa kombinasi produk, jasa, informasi atau pengalaman yang ditawarkan ke pasar untuk memuaskan suatu kebutuhan atau keinginan. Penawaran pasar tidak terbatas pada produksi fisik. Penawaran pasar juga meliputi penawaran jasa, aktivitas atau keuntungan untuk dijual yang pada intinya tidak berwujud dan tidak menghasilkan kepemilikan apapun. Beberapa penjual sering membuat kesalahan karena mereka lebih memperhatikan produk khusus yang mereka tawarkan daripada manfaat dan pengalaman oleh produk produk tersebut. Mereka terfokus pada keinginan dan tidak memperhatikan kebutuhan pelanggan yang mendasarinya, hal ini bisa disebut penderita rabun jauh pemasaran (marketing myopia).

\section{Nilai dan Kepuasan Pelanggan}

Empat langkah pertama dalam proses pemasaran melibatkan hubungan pelanggan dengan menciptakan dan menghantarkan nilai pelanggan yang unggul. Dengan menciptakan nilai pelanggan yang unggul, perusahaan menciptakan pelanggan yang sangat puas dan tetap setia, serta mau membeli lagi. Hal ini berarti keuntungan jangka panjang yang lebih besar untuk perusahaan. Hasil dari penciptaan nilai pelanggan yaitu :

- Menciptakan kesetiaan dan retensi pelanggan;

○ Menumbuhkan pangsa pasar pelanggan; dan

- Membangun Ekuitas pelanggan.

Menciptakan kesetiaan dan retensi pelanggan yaitu menciptakan hubungan yang baik sehingga tercapainya kepuasan pelanggan, sehingga konsumen tetap setia dan menceritakan hal-hal yang baik tentang perusahaan lewat produk atau jasanya kepada orang lain. Hal ini biasa disebut dengan nilai seumur hidup pelanggan (costumer lifetime value). Perusahaan harus menetapkan tujuan yang tinggi dalam membangun hubungan pelanggan secara emosional dengan produk atau jasa bukan hanya preferensi rasional.

Menumbuhkan pangsa pelanggan (share of costumer), dapat membantu atau membina hubungan baik dengan konsumen dengan cara menawarkan ragam jenis produk atau jasa yang ditawarkan kepada pelanggan lama. Dengan cara seperti ini dapat meningkatkan lebih besar pangsa pasar mereka.

Membangun ekuitas pelanggan (costumer equity) adalah gabungan nilai seumur hidup pelanggan dari semua pelanggan baru dan pelanggan potensial. Semakin tinggi kestiaan pelanggan terhadap suatu produk atau jasa, semakin tinggi pula ekuitas pelanggan perusahaan. Ekuitas pelanggan dapat menjadi ukuran hasil kinerja yang lebih baik dari penjualan terbaru atau pangsa pasar. 
Kepuasan pelanggan berjalan berbarengan dengan ketidakpuasan. Artinya respons pelanggan terhadap evaluasi dan ketidaksesuaian yang dirasakan antara harapan sebelumnya dan kinerja produk yang dirasakan setelah pemakaiannya. Jadi kepuasan adalah suatu tanggapan emosional yang dirasakan oleh pelanggan pada saat menikmati pengalaman menggunakan atau mengonsumsi produk atau jasa. Dengan demikian kepuasan pelanggan adalah evaluasi pasca pembelian, dimana alternatif yang dibeli minimal sama atau melebihi harapan pelanggan. Berdasarkan pengertian ini, maka kepuasan pelanggan adalah tingkat perasaan seseorang setelah membandingkan kinerja atau hasil yang ia rasakan dibandingkan dengan harapannya.

Pemasar harus berhati-hati dalam menentukan tingkat ekspektasi pasar yang tepat. Jika mereka menetapkan ekspektasi terlalu rendah, mereka mungkin memuaskan pelanggan yang membelikan produk itu tetapi gagal menarik cukup banyak pembeli. Jika perusahaaan menaikkan ekspektasi terlalu tinggi, konsumen akan kecewa. Nilai dan kepuasan pelanggan merupakan kunci-kunci untuk mengembangkan dan menata hubungan pelanggan. Konsumen yang tidak puas akan berganti ke pesaing dan menjelek-jelekkan produk yang mereka beli kepada orang lain. Pelanggan yang puas akan membeli lagi dan meberitahu orang lain tentang pengalaman baik mereka

Beberapa pengertian kepuasan pelanggan menurut para ahli :

- Respons atau tanggapan konsumen mengenai kebutuhan. Kepuasan merupakan penilaian mengenai ciri atau keistimewaan produk atau jasa, atau produk itu sendiri, yang menyediakan tingkat kesenangan konsumen berkaitan dengan pemenuhan kebutuhan konsumen (Zeithaml dan Bitner (2000:75).

- Kepuasan konsumen adalah sejauh mana anggapan kinerja produk memnuhi harapan pembeli. Bila kinerja produk lebih tinggi ketimbang harapan pelanggan, maka pembelinya merasa puas atau amat gembira. Kotler dan Armstrong (2001:9)

- Kepuasan pelanggan merupakan perasaan seseorang terhadap kinerja suatu produk atau jasa yang dibandingkan dengan harapannya. (Schiffman).

- Kepuasan adalah konsep yang jauh lebih luas dari hanya sekedar penilaian kulaitas pelayanan, tetapi juga dipengaruhi oleh faktor-faktor lain (Ziethaml).

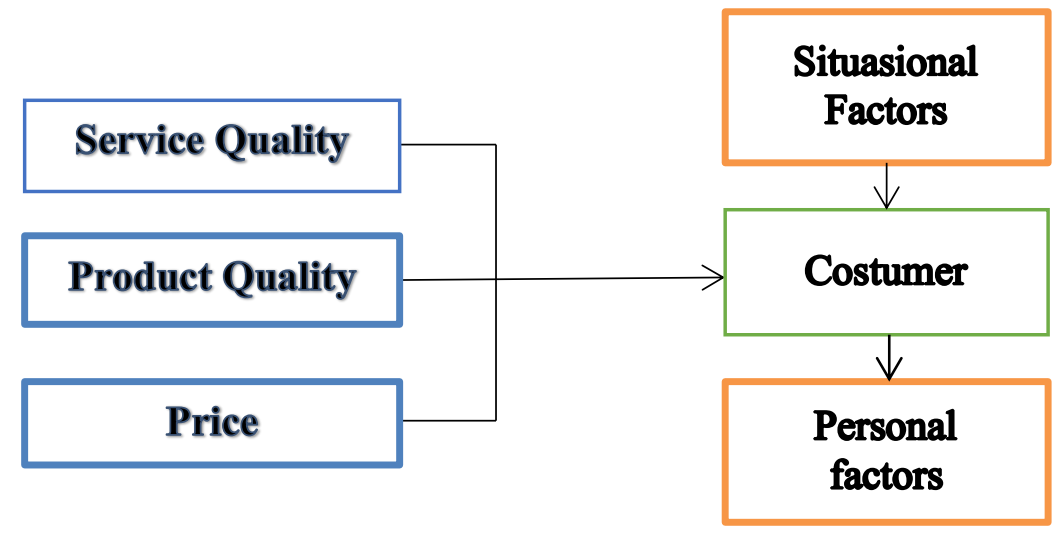


Gambar 2. Costumer Service Satisfaction \& Call Centre (Freddy Rangkuti, 2013)

Dapat disimpulkan melalui berbagai pengertian diatas bahwa kepuasan pelanggan dipengaruhi oleh berbagai faktor, yaitu :

1. Service Quality;

2. Product Quality;

3. Price;

4. Situational factor; and

5. Personal factor

Service quality merupakan kualitas jasa pelayanan yang kita berikan kepada pelanggan. Tidak ada gunanya produk berkualitas kalau tidak diimbangi dengan kualitas pelayanan yang luar biasa. Pelanggan akan merasa kecewa karena tidak dilayani dengan baik. Sebaliknya, pelayanan yang luar biasa juga tidak ada artinya apabila tidak didukung oleh produk yang berkualitas serta harga yang sesuai dengan harapan pelanggan.

Selain itu, strategi peningkatan kepuasan pelanggan juga sangat dipenagaruhi oleh faktor-faktor internal yang ada dalam diri pelanggan itu sendiri, seperti faktor situasional dan personal. Seringkali kita hanya berjalan-jalan untuk melihat di pusat perbelanjaan. Namun apabila pengaruh situasional, misalnya ada kegiatan promosi, diskon, menjelang lebaran, tahun baru, serta berbagai kegiatan dapat meningkatkan impulse buying, maka faktor situasional dapat mempengaruhi proses pengambilan keputusan kita dalam melakukan pembelian yang tidak kita rencanakan sebelumnya.

Begitu juga faktor personal, orang yang memiliki karakter suka berbelanja, banyak mempengaruhi gaya hidup dan proses pengambilan keputusan untuk pembelian.

\subsection{Fungsi dan Orientasi Manajemen Pemasaran}

Di dalam fungsi manajemen pemasaran ada kegiatan menganalisis yaitu analisis yang dilakukan untuk mengetahui pasar dan lingkungan pemasarannya, sehingga dapat diperoleh seberapa besar peluang untuk merebut pasar dan seberapa besar ancaman yang harus dihadapi

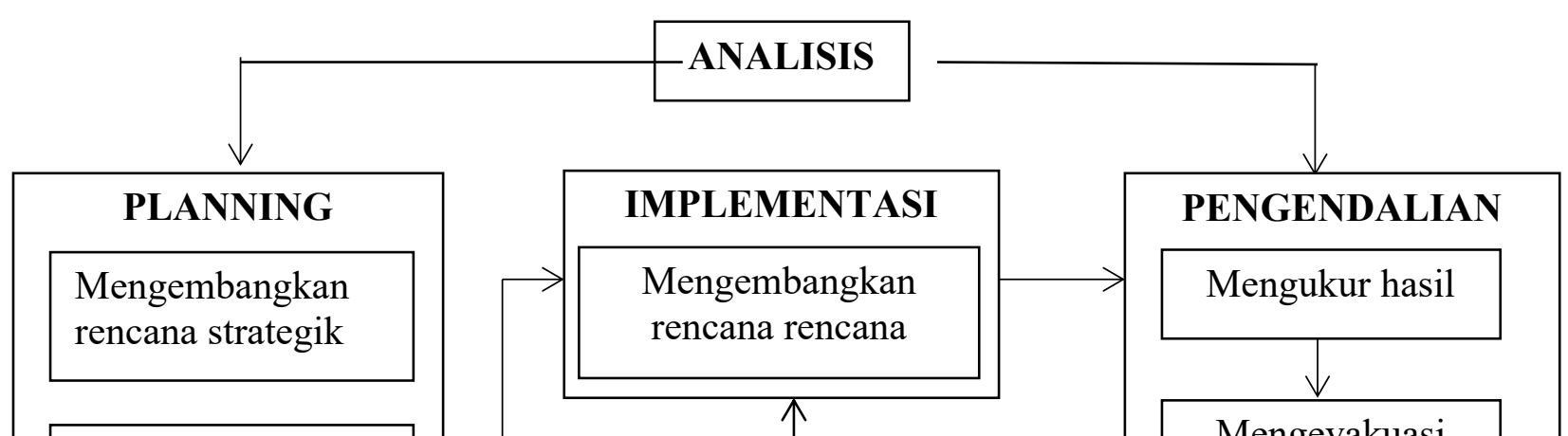


Penjelasan fungsi manajemen yang merupakan kegiatan terpadu dan saling mendukung, antara lain :

\section{a. Perencanaan Pemasaran}

Perencanaan segala sesuatu sebelum dilakukan kegiatan-kegiatan pemasaran meliputi : tujuan, strategi, kebijaksanaan serta taktik yang dijalankan.

Tujuan : - meniadakan ketidakpastian masa datang apabila ada perubahan-perubahan karena situasi dan kondisi perusahaan yang tidak menentu.

$>$ Karena tujuan organisasi sudah difokuskan maka dengan perencanaan akan menghindari adanya penyimpangan tujuan.

Rencana walaupun mahal tetapi ekonomis karena segala kegiatan telah terfokus dengan segala biaya-biayanya.

$>$ Rencana pemasaran terperinci diperlukan untuk setiap bisnis, produk atau merk.

Sebagai syarat minimal perencanaan harus berisi bagian-bagian sebagai berikut :

\section{BAGIAN}

1. Ringkasan bagi eksekutif

\section{TUJUAN}

Menyajikan pandangan singkat atas rencana yang diusulkan agar dapat ditinjau dengan cepat oleh manajemen. 
2. Situasi pemasaran saat ini

3. Analisis ancaman dan peluang

4. Sasaran dan Isu

5. Strategi pemasaran

6. Program tindakan

7. Anggaran

8. Pengendalian
Menyajikan data latar belakang yang relevan mengenai pasar, produk, persaingan dan distribusi.

Mengidentifikasi ancaman dan peluang utama yang mempengaruhi produk.

Menentukan sasaran perusahaan untuk produk di bidang penjualan, pangsa pasar, laba serta isu yang akan mempengaruhi sasaran ini.

Menyajikan pendekatan pemasaran yang luas, yang digunakan untuk mencapai sasaran dalam rencana.

Menspesifikasikan apa yang akan dilakukan, siapa yang melakukannya, kapan dan berapa biayanya.

Laporan laba rugi yang diproyeksikan yang meramalkan hasil keuangan yang diharapkan dari rencana tadi.

Menunjukkan bagaimana kemajuan rencana akan dipantau.

\section{b. Implementasi Pemasaran}

Adalah proses yang mengubah strategi dan rencana pemasaran menjadi tindakan pemasaran untuk mencapai sasaran. Implementasi mencakup aktivitas sehari-hari secara efektif melaksanakan rencana pemasaran. Kegiatan ini dibutuhkan program tindakan yang menarik semua orang atau semua aktivitas serta struktur organisasi formal yang dapat memainkan peranan penting dalam mengimplemntasikan strategi pemasaran.

Implementasi yang sukses tergantung dari beberapa kegiatan kunci, yaitu :

Pengorganisasian kegiatan pemasaran yaitu :

Proses menciptakan hubungan antara fungsi personalia dan faktor fisik (sarana), agar kegiatan pemasaran yang harus dilaksanakan bisa mencapai tujuan yang benar, meliputi : pembagian kerja, wewenang, tanggung jawab dan pelaporan kerja. Hal ini bertujuan untuk setiap orang di dalam organisasi bertanggung jawab dalam melaksanakan 
kegiatan pemasaran yang telah dibebankan kepadanya sehingga tidak overlapping pekerjaan.

Bentuk umum dalam departemen yang modern, antara lain :

- Organisasi fungsional dimana berbagai aktivitas pemasaran yang berbeda dikepalai oleh spesialis fungsional : manajemn penjualan, periklanan, riset pemasaran, pelayana terhadap pelanggan, manajemen produk baru.

- Organisasi geografik, dimana karyawan bagian penjualan dan pemasaran diberi tugas di negara, wilayah atau distrik tertentu.

- Organisasi manajemen produk, karyawan ini mengembangkan pemasaran dan strategi lengkap untuk produk atau merk tertentu, bila perusahaan ini mempunyai produk atau merk yang amat berbeda.

- Bila firm yang mejual satu lini produk kepada banyak tipe pasar berbeda yang mempunyai organisasi manajemen pasar. Manajer ini bertanggung jawab untuk mengembangkan rencana jangka panjang dan tahunan untuk keunggulan utama dari sistem ini.

* Pengarahan kegiatan pemasaran, yaitu :

Usaha yang berhubungan dengan segala sesuatu kegiatan pemasaran agar semuanya itu dapat dilakukan dengan baik meliputi :

- Pemberian perintah secara baik, harus ada follow-up-nya, secara sederhana, perlu penjelasan sehingga ada pengertian dan sifatnya harus konsultatif;

- Motivasi; dan

- Kepemimpinan.

Dengan pengarahan segala kegiatan yang menyimpang akan terdeteksi dan pimpinan dapat memberikan motivasi untuk meghasilkan sesuatu yang sesuai dengan harapan agar terjadi harmonisasi antar anggota organisasi / firm.

* Pengkoordinasian kegiatan pemasaran, yaitu :

> Usaha mengsinkronkan dan menyatukan segala kegiatan pemasaran dalam organisasi agar tercapai tujuan yang efektif dan efisien.

Cara - cara menjalankan koordinasi yang efektif, dengan cara yaitu :

1. Diadakan prosedur yang terang dan jelas dan ditentukan tanggal penyelesaian (dead line). 
2. Koordinasi dilakukan secara formal melalui pimpinan staff pembantu, panitia atau pejabat penghubung.

\section{c. Pengendalian / Evaluasi kegiatan pemasaran, yaitu :}

Usaha memberikan petunjuk pada para pelaksana agar mereka selalu bertindak sesuai dengan rencana meliputi :

- Penentuan standard;

- Supervisi kegiatan atas pemeriksaan;

- Perbandingan hasil dengan Standard; dan

- Kegiatan mengkoreksi Standard.

\begin{tabular}{|c|c|c|c|}
\hline $\begin{array}{l}\text { Menetapkan } \\
\text { Sasaran }\end{array}$ & $\begin{array}{l}\text { Mengukur } \\
\text { kinerja }\end{array}$ & $\begin{array}{l}\text { Mengevaluasi } \\
\text { kinerja }\end{array}$ & $\begin{array}{l}\text { Mengambil tindakan } \\
\text { perbaikan / solusi }\end{array}$ \\
\hline $\begin{array}{l}\text { Apa yang ingin } \\
\text { dicapai }\end{array}$ & Apa yang & Mengapa hal & \multirow{2}{*}{$\begin{array}{l}\text { Apa yang harus } \\
\text { dilakukan } \\
\text { mengenai hal } \\
\text { tersebut? }\end{array}$} \\
\hline & terjadi ? & ini terjadi & \\
\hline
\end{tabular}

Gambar 4. Proses pengevaluasian kegiatan pemasaran

Kegiatan pengendalian / evaluasi di atas dapat dikelompokkan dua macam :

1. Pengendalian operasional termasuk memeriksa kinerja yang berlangsung terhadap rencana dan mengambil tindakan perbaikan kalau perlu. Tujuannya adalah memastikan bahwa perusahaan mencapai penjualan, laba dan sasaran lain yang ditetapkan dalam rencana tahunannya. Kegiatan ini juga mencakup penentuan produk, wilayah, pasar dan saluran yang berbeda yang dapat mendatangkan laba.

2. Pengendalian strategik meliputi pengamatan apakah strategi dasar perusahaan sesuai dengan peluang yang terbuka.

\section{Orientasi Manajemen Pemasaran}

Orientasi manajemen pemasaran adalah perancangan strategi pemasaran harus berhubungan dengan konsumen sebagai sasaran, atau berorientasi kepada kepentingan konsumen, organisasi dan masyarakat. Perusahaan harus mengetahui filosofi apa yang digunakan dalam memandu strategi pemasaran, maka dari itu fungsi manajerial yang bertujuan kepada orientasi manajemen pemasaran harus memiliki konsep untuk perancangan strategi 
pemasaran. Ada lima konsep atau falsafah yang digunakan untuk mendasari langkah-langkah organisasi dalam merancang dan melaksanakan ide strategi pemasaran mereka, yaitu :

- Konsep produksi;

○ Produk;

○ Penjualan;

- Pemasaran; dan

- Pemasaran berwawasan sosial.

\section{Konsep Produksi (Production Concept)}

Konsep produksi bahwa konsep atau strategi yang memfokuskan efisiensi distribusi dan jumlah produksi dengan kuantitas yang berjumlah banyak dengan maksud agar produk selalu tersedia karena biaya produksinya untuk menciptakan produk menggunakan biaya yang murah atau terjangkau. Konsep produksi ini masih menjadi filosofi yang bermanfaat dalam beberapa situasi. Perusahaan yang menetapkan orientasi ini berisiko karena terlalu memfokuskan diri pada operasi mereka sendiri dan kehilangan pandangan tujuan yang sebenarnya.

\section{Konsep Produk (Product Concept)}

Konsep atau falsafah ini menjelaskan bahwa konsumen lebih menyukai produk yang bermutu tinggi dengan kualitas, kinerja dan fitur inovatif yang terbaik. Perusahaan yang menghasilkan produk atau jasa harus lebih banyak mengeluarkan kemampuan atau energi dalam inovasi untuk menciptakan strategi pemasaran berfokus pada perbaikan produk yang berkelanjutan. Suatu produk tidak akan sukses jika tidak didukung oleh harga, iklan dan penjualan yang tepat.

\section{Konsep Penjualan (Selling Concept)}

Konsep atau falsafah ini menjelaskan bahwa konsumen tidak akan membeli produk perusahaan kecuali jika produk itu dijual dalam skala besar. Konsep ini biasanya dilakukan kepada barang-barang yang tidak dicari seperti, asuransi, ensiklopedi. Industri ini harus melacak prospek dan menjual produk berdasarkan manfaat produk. Penjualan seperti ini harus dilakukan secara agresif karena mengandung resiko tinggi terhadap target penjualan karena menitikberatkan kepada penciptaan transaksi penjualan dan bukan pembangunan hubungan 
pelanngan jangka panjang. Konsep ini menitikberatkan bagaimana cara menjual produk yang dihasilkan oleh perusahaan bukan karena keinginan pasar.

\section{Konsep Pemasaran (Marketing Concept)}

Konsep atau falsafah pemasaran ini berkeyakinan bahwa pencapaian sasaran organisasi tergantung pada penentuan kebutuhan dan keinginan pasar sasaran bertujuan fokus pada kepuasan pelanggan, sehingga mampu bersaing lebih baik daripada pesaing. Konsep ini adalah berfokus pada nilai dan pelanggan adalah jalan menuju teget penjualan. Pekerjaan yang dilakukan oleh seorang manajer pemasaran bukanlah menemukan pelanggan yang tepat bagi produk yang dijual, tetapi menemukan produk yang tepat bagi pelanggan anda.

Konsep ini berbanding terbalik dengan konsep penjualan, karena fokus pada konsep penjualan adalah dengan menggunakan produk yang sudah ada, sarana berfokus pada saluran penjualan dan menggunakan promosi supaya memberi daya tarik kepada pelanggan dan nilai akhir yang dituju adalah keuntungan dengan volume penjualan, sedangkan konsep pemasaran berfokus pada kebutuhan pelanggan, sarana pendistribusiannya dengan pemasaran yang terintegrasi dan nilai akhir yang dituju dalam konsep pemasaran adalah keuntungan melalui kepuasan pelanggan. Tugas pemasaran bukanlah mencari pelanggan yang tepat untuk produk anda, melainkan menemukan produk yang tepat untuk pelanggan.

\begin{tabular}{|c|c|c|c|c|}
\hline & Titik Awal & Fokus & Metode & Akhir \\
\hline $\begin{array}{l}\text { Konsep } \\
\text { penjualan }\end{array}$ & Pabrik & $\begin{array}{l}\text { Produk yang } \\
\text { sudah ada }\end{array}$ & $\begin{array}{l}\text { Penjualan dan } \\
\text { promosi }\end{array}$ & $\begin{array}{c}\text { Keuntungan } \\
\text { melalui volume } \\
\text { penjualan }\end{array}$ \\
\hline
\end{tabular}

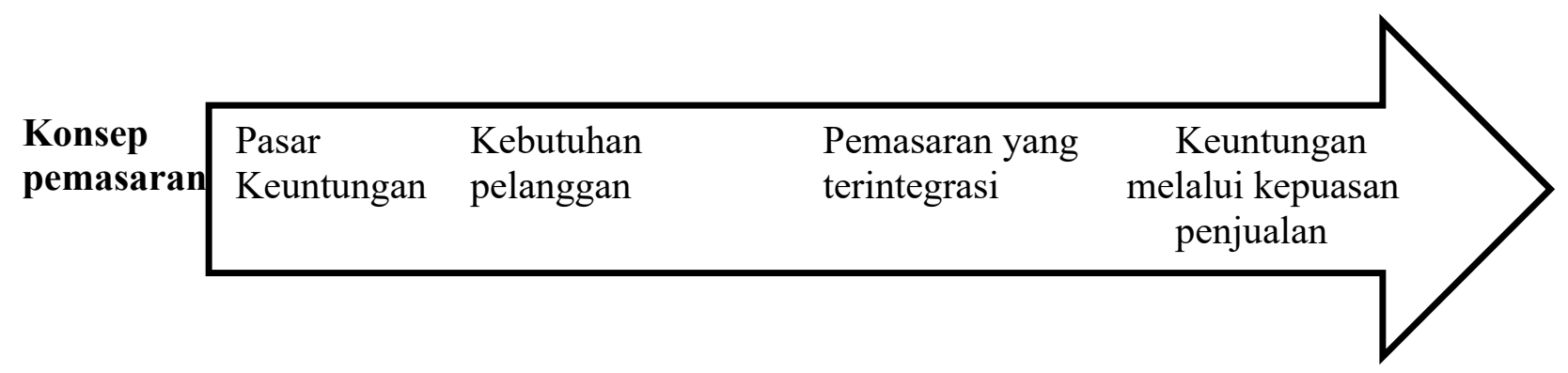


"Theodore Levitt dari Harvard menjelaskan perbedaan antara konsep penjualan dengan konsep pemasaran :

Penjualan berfokus pada kebutuhan penjual; pemasaran berfokus pada kebutuhan pembeli. Penjualan didasari oleh kebutuhan penjual untuk megubah produknya menjadi uang; pemasaran didasari oleh gagasan untuk memuaskan kebutuhan pelanggan melalui produk dan hal-hal yang berhubungan dengan menciptakan, menghantarkan, dan akhirnya mengkonsumsinya

(Sumber : Philip Kotler \& Gary Armstrong, edisi 12, 2008)

\section{Konsep Pemasaran Berwawasan Sosial (societal marketing concept).}

Konsep atau falsafah pemasaran berwawasan sosial menerangkan bahwa organisasi atau perusahaan harus menentukan kebutuhan, keinginan, dan minat pasar serta menyerahkan kepuasan yang didambakan itu secara lebih efektif dan efisien daripada pesaing dengan cara yang bersifat memelihara atau memperbaiki kesejahteraan konsumen dan masyarakat. Konsep ini mengajak pemasar membangun pertimbangan sosial dan etika dalam praktek pemasaran mereka. Hal ini dapat menyeimbangkan dari ketiga sisi faktor tersebut yaitu : laba, perusahaan, pemuas keinginan konsumen dan kepentingan publik.

\subsection{Audit Pemasaran}

Suatu alat untuk melakukan pengendalian strategik dalam pemasaran produk atau jasa adalah Audit Pemasaran. Audit pemasaran adalah pemeriksaan lingkungan, sasaran, strategi, dan aktivitas perusahaan secara lengkap, sistematik, independen dan periodik untuk menentukan bidang masalah dan peluang. Audit memberikan masukan yang baik untuk merencanakan tindakan perbaikan presentasi kerja pemasaran.

Audit pemasaran mencakup seluruh bidang sasaran utama dari suatu bisnis, bukan terbatas pada beberapa masalah yang muncul. Biasanya audit pemasaran dilakukan oleh pihak lain yang obyektif, berpengalaman dan independen terhadap departemen pemasaran.

\section{Audit Lingkungan Pemasaran}

\section{Lingkungan Makro}

\begin{tabular}{|c|c|l|}
\hline NO & FAKTOR & \multicolumn{1}{c|}{ KETERANGAN } \\
\hline 1 & Demografi & Kecendrungan apa yang menimbulkan ancaman dan peluang ? \\
\hline 2 & Ekonomi & $\begin{array}{l}\text { Perkembangan apa dalam pendapatan, harga tabungan, dan kredit } \\
\text { akan berdampak pada perusahaan? }\end{array}$ \\
\hline 3 & Alami & $\begin{array}{l}\text { Bagaimana perkiraan biaya dan ketersediaan sumberdaya alam dan } \\
\text { energi? Apakah perusahaan bertanggungjawab memelihara } \\
\text { lingkungan? }\end{array}$ \\
\hline
\end{tabular}




\begin{tabular}{|c|c|l|}
\hline 4 & Teknologi & $\begin{array}{l}\text { Perubahan teknologi apa yang sedang berlangsung? } \\
\text { Bagaimana posisi perusahaan dalam teknologi ? }\end{array}$ \\
\hline 5 & Politik & $\begin{array}{l}\text { Undang-undang apa yang sudah berlaku dan sedang dibahas akan } \\
\text { mempengaruhi strategi pemasaran? }\end{array}$ \\
\hline 6 & Budaya & $\begin{array}{l}\text { Bagaimana sikap publik terhadap bisnis dari perusahaan ? } \\
\text { Perubahan apa dalam gaya hidup konsumen yang mungkin } \\
\text { mempunyai dampak }\end{array}$ \\
\hline
\end{tabular}

\section{Lingkungan Mikro}

\begin{tabular}{|c|c|l|}
\hline NO & FAKTOR & \multicolumn{1}{|c|}{ KETERANGAN } \\
\hline 1 & Pasar & $\begin{array}{l}\text { Apa yang sering terjadi pada ukuran pasar, pertumbuhan, distribusi } \\
\text { geografi dan laba? }\end{array}$ \\
\hline 2 & Pelanggan & $\begin{array}{l}\text { Bagaimana pandangan pelanggan mengenai mutu, produk, jasa } \\
\text { dan harga? }\end{array}$ \\
\hline 3 & Pesaing & $\begin{array}{l}\text { Siapa pesaing utama? Apa strategi yang dipakainya, berapa pangsa } \\
\text { pasarnya dan apa kekuatan serta kelemahannya? }\end{array}$ \\
\hline 4 & Saluran distribusi & $\begin{array}{l}\text { Saluran utama apa yang dipakai perusahaan untuk } \\
\text { mendistribusikan produk kepada pelanggan ? Bagaimana } \\
\text { presentasi kerjanya? }\end{array}$ \\
\hline 5 & Pemasok & $\begin{array}{l}\text { Kecendrungan apa yang mempengaruhi pemasok? Bagaimana } \\
\text { perkiraan ketersediaan sumber daya kunci untuk produksi? }\end{array}$ \\
\hline 6 & Publik & $\begin{array}{l}\text { Kunci mana yang membawa masalah atau peluang? } \\
\text { Bagaimana perusahaan menghadapi public ini? }\end{array}$ \\
\hline
\end{tabular}

\section{Audit Pemasaran}

1. Misi bisnis. Apakah misi diuraikan dengan jelas dan berorientasi pada pasar ?

2. Obyektif pemasaran. Apakah perusahaan sudah menerapkan obyektif yang jelas sebagai pedoman perencanaan pemasaran dan mengukur presentasi? Apakah obyektif ini cocok dengan peluang perusahaan dan sumber dayanya?

3. Strategi pemasaran. Apakah perusahaan mempunyai strategi pemasaran yang mantap untuk mencapai obyektifnya?

4. Anggaran. Apakah perusahaan menganggarkan sumber daya yang cukup untuk segmen, produk, wilayah dan unsur-unsur eleven bauran pemasaran ?

\section{Audit Organisasi Pemasaran}

1. Struktur formal. Apakah kepala bagian pemasaran mempunyai wewenang yang memadai atas aktivitas yang mempengaruhi kepuasan pelanggan? Apakah kegiatan pemasaran secara optimal disusun lini fungsi, produk, pasar dan teritori ? 
2. Efisiensi fungsi. Apakah pemasaran dan penjualan berkomunikasi secara efektif? Apakah staff pemasaran dilatih, disupervisi,cdimotivasi dan dievaluasi dengan baik.

3. Efisiensi antar bagian. Apakah staff pemasaran bekerjasama dengan baik dengan bagian manufaktur, litbang, pembelian dan bidang-bidang non pemasaran yang lain?

\section{Audit Sistem Pemasaran}

1. Sistem informasi pemasaran. Apakah sistem intelijen pemasaran menyediakan informasi akurat dan tepat waktu mengenai perkembangan pasar? Apakah pembuat keputusan perusahaan menggunakan riset pemasaran dengan efektif?

2. Sistem perencanaan pemasaran. Apakah perusahaan menyiapkan rencana tahunan, jangka panjang dan strategik? Apakah rencana tersebut digunakan?

3. Sistem pengendalian pemasaran. Apakah obyektif tahunan pemasaran tercapai? Apakah manajemen secara periodik menganalisis penjualan dan laba yang dihasilkan oleh produk, pasar,teritori dan saluran distribusi?

4. Pengembangan produk baru. Apakah perusahaan terorganisasi dengan baik untuk menghasilkan dan menyaring ide produk baru? Apakah perusahaan melaksanakan pengujian yang memadai menyangkut produk baru? Apakah perusahaan melaksanakan pengujian terhadap produk dan pasar? Apakah perusahaan berhasil dengan produk baru?

\section{Audit Produktivitas Pemasaran}

1. Analisis Kemampuan menghasilkan laba. Seberapa besar laba yang mampu dihasilkan dari berbagai produk, pasar, teritori dan saluran distribusi yang berbeda ?

2. Analisis efektifitas biaya. Apakah ada aktivitas pemasaran yang menyerap biaya berlebihan? Bagaimana mengurangi biaya tadi?

\section{Audit Fungsi Pemasaran}

1. Produk. Apakah perusahaan mengembangkan obyektif lini produk yang mantap? Apakah beberapa produk sebaiknya ditarik? Apakah ada produk baru yang perlu ditambahkan? Apakah ada produk yang akan memperoleh manfaat dari perusahaan mutu, gaya atau sifat? 
2. Harga. Apa yang menjadi obyektif, strategi, kebijan dan prosedur penetapan harga yang dianut perusahaan? Apakah promosi harga dipergunakan dengan tepat?

3. Distribusikan. Apa yang menjadi obyektif dan strategi distribusi? Apakah liputan dan pelayanan pasar memadai? Apakah saluran distribusi yang sudah ada sekarang sebaiknya dirubah atau ditambah yang baru?

4. Iklan, promosi, penjualan dan publisitas. Apa yang menjadi obyektif promosi perusahaan? Bagaimana anggaran ditetapkan? Apakah anggaran mencukupi? Apakah pesan iklan dan media dikembangkan dan diterima dengan baik? Apakah perusahaan mempunyai program promosi penjualan dan hubungan masyarakat yang dikembangkan dengan baik.

5. Tenaga penjualan. Apa yang menjadi obyektif armada tenaga penjualan perusahaan? Apakah jumlah tenaga penjualan cukup dilatih, disupervisi, dan dimotivasi dengan baik? Bagaimana tenaga penjualan ini kalau dibandingkan dengan armada milik pesaing?

(Disadur dari Kottler, 2000)

\subsection{Rangkuman}

Pemasaran adalah proses membangun hubungan pelanggan yang menguntungkan dengan menciptakan nilai bagi pelanggan dan menangkap kembali nilai dari pelanggan. Tujuan 
pemasaran adalah membangun dan menata hubungan pelanggan yang menguntungkan. Pemasaran berusaha menarik pelanggan mempertahankan dengan menjanjikan nilai unggul dan untuk mempertahankan dan menunbuhkan pelanggan yang ada dengan memberikan kepuasan. Dalam menentukan strategi pemasaran diperlukan tahapan dalam proses pemasaran yaitu :

1. kebutuhan, keinginan dan permintaan;

2. penawaran pemasaran (produk, jasa dan pengalaman);

3. nilai dan kepuasan;

4. pertukaran dan hubungan; dan

5. pasar.

Fungsi manajemen pemasaran yang merupakan kegiatan terpadu dan saling mendukung, antara lain:

1. Perencanaan Pemasaran;

2. Implementasi Pemasaran; dan

3. Pengendalian / Evaluasi kegiatan pemasaran.

Lima konsep atau falsafah yang digunakan untuk mendasari langkah-langkah organisasi dalam merancang dan melaksanakan ide strategi pemasaran mereka, yaitu :

1. Konsep produksi;

2. Produk;

3. Penjualan;

4. Pemasaran; dan

5. Pemasaran berwawasan sosial.

Audit pemasaran adalah pemeriksaan lingkungan, sasaran, strategi, dan aktivitas perusahaan secara lengkap, sistematik, independen dan periodik untuk menentukan bidang masalah dan peluang. Jenis - jenis audit pemasaran adalah :

1. Audit Lingkungan Pemasaran;

2. Audit Pemasaran;

3. Audit Organisasi Pemasaran;

4. Audit Sistem Pemasaran;

5. Audit Produktivitas Pemasaran;

6. Audit Fungsi Pemasaran. 


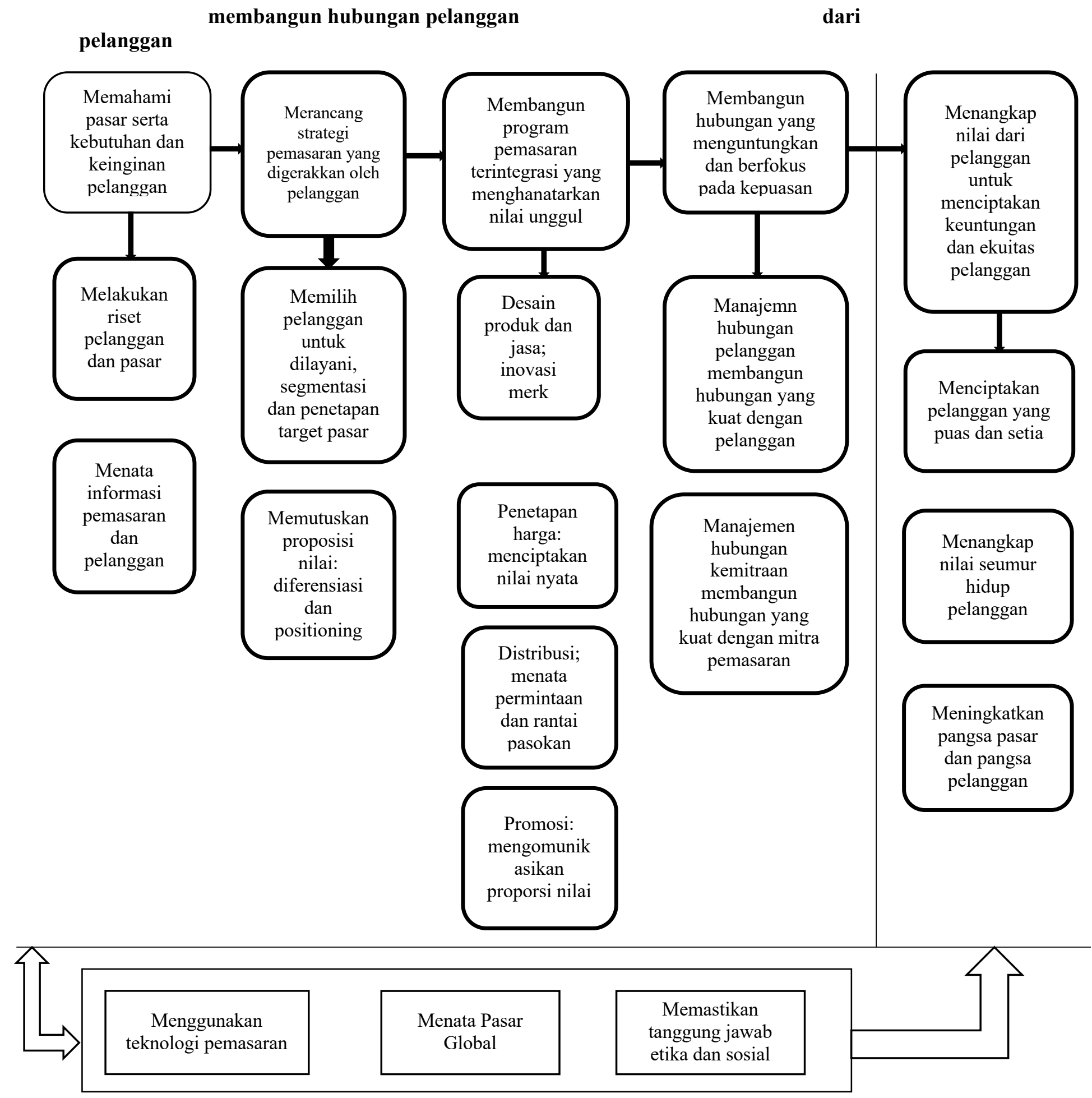

Gambar 6. Model proses pemasaran yang diperluas ( Kotler \& Armstrong, 2008)

\subsection{Soal untuk Diskusi}

1. Uraikan pengertian dari Pemasaran dan Manajemen Pemasaran yang anda ketahui beserta peranan dan tujuan pemasaran tersebut. 
2. Jelaskan konsep atau falsafah manajemen pemasaran.

3. Ada perbedaan antara konsep penjualan dan konsep pemasaran, apakah yang menyebabkan perbedaan itu ? Mengapa konsep pemasaran sekarang lebih popular dibanding konsep penjualan ?

4. Berikan beberapa contoh perusahaan yang sudah mematuhi konsep pemasaran berwawasan sosial?

5. Dampak apa yang terjadi jika suatu perusahaan tidak menetapkan strategi pemasaran dengan konsep pemasaran yang jelas dan seberapa pentingnya fugsi audit pemasaran dalam mengeavaluasi strategi atau konsep pemasaran tersebut. 